ISSN 1991-8631

Original Paper

http://indexmedicus.afro.who.int

\title{
Determination of glyphosate by high performance liquid chromatography (HPLC) without prior extraction
}

\author{
Marc Irié Gouli BI ${ }^{1 *}$, Aboua Jacques YAPO ${ }^{1}$, Ardjouma DEMBELE ${ }^{2}$, \\ Aimé Serge ELLO ${ }^{1}$ and Albert TROKOUREY ${ }^{1}$ \\ ${ }^{1}$ UFR SSMT, Laboratoire de Chimie Physique, Université de Cocody, 22 BP 582 Abidjan 22, Côte d'Ivoire. \\ ${ }^{2}$ Laboratoire Central d'Agrochimie et d'Ecotoxicologie (LCAE), Côte d'Ivoire. \\ *Corresponding author, E-mail: trokourey@yahoo.com
}

\begin{abstract}
The aim of this study was to design a glyphosate analysis method. This molecule is an organic pollutant from water and soil. We have developed a chromatographic method with phenylisothiocyanate. This molecule has allowed obtaining an intermediate molecule with the glyphosate being easily detectable in chromatography. The peak relating to this intermediate was identified using a comparison with several samples, including a blank. The tests determined the retention time (RT) of glyphosate at $1.6 \mathrm{~min}$ and the values of the percentage of accuracy and repeatability of the method.
\end{abstract}

(C) 2011 International Formulae Group. All rights reserved.

Keywords: Glyphosate, phenylisothiocyanate, liquid chromatography, detection limit, Phénylthiocarbamoylglphosate, retention time.

\section{INTRODUCTION}

Glyphosate [N-(phosphonomethyl) glycine, $\mathrm{HOOC}-\mathrm{CH}_{2}-\mathrm{CH}_{2}-\mathrm{NH}-\mathrm{PO}_{3} \mathrm{H}_{2}$ ] is a non-selective amino-phosphonate herbicide. It was introduced in agriculture since 1974 by Monsanto Company (Baylis, 2000; James, 2006) and it is very much used (Woodbum, 2000). Glyphosate is known as an environmentally-friendly herbicide due to its biodegradation and adsorption in soil. The lower concentrations of glyphosate have been found in shallow aquifers, which challenge the common idea that glyphosate has limited mobility in soils (Barja et al., 2005; Vereecken, 2005). This herbicide is highly toxic after a threshold of $0.1 \mu \mathrm{g} . \mathrm{L}^{-1}$ into the groundwater and has an effect on human placental cells (Richard et al., 2005) leading to spontaneous death or abortions (Savitz, 2000), therefore, it is important to remove these organic pollutants from the contaminated water and soil.

The aim of this study was to design a method of analysis of glyphosate in water, and to provide method of elimination. On the other hand, several other methods have already been developed but have shown their inefficiency. In fact, glyphosate can exist in different ionic forms depending on $\mathrm{pH}$ effects on its functional groups (carboxylic acid, 
phosphonic acid and secondary amine), which makes it very soluble in water $\left(12.0 \mathrm{~g} . \mathrm{L}^{-1}\right.$ at $25{ }^{\circ} \mathrm{C}$ ) (Tortensson, 2008). The conventional removal liquid-liquid methods cannot be applied to the analysis of glyphosate. In addition, this molecule is rapidly degraded to aminophosphonic acid (AMPA) as amine form. The 9-fluorenylmethylchloroformate (FMOC) is often used as intermediate products to determine the amount of glyphosate (Sancho et al., 1996; Tsui et al., 2008). However, we are inspired by the PicoTag method, described by Heinrikson and Meredith (1984). The technique was developed to improve the speed sensibility to amino-acid analysis with phénylisothiocyanate for the rapid separation of very small amounts of complex peptides and protein mixtures (Bidlingmeyer et al., 1987).

\section{MATERIALS AND METHODS Materials}

The following materials were used: HPLC (PROMIN 20AT Shimadzu) equipped with two pumps (LC 20A); an automatic injector (SIL-20A); a hot column (CTO-20A); Interchrom $\mathrm{C}_{18}$ column $(5 \mu \mathrm{m}$ particle size, Length x I.D: $250 \mathrm{~mm}$ x $4.6 \mathrm{~mm}$ ); Detector Sensitivity (1 AUFS) and a computer system to check solvent gradient.

\section{Methods}

\section{Sample preparation}

Glyphosate (77\% purity, made in France by Arysta LifeScience) was used. Thus, the following solutions were used: solution S1 made of a mixture of ethanol, water, phenylisothiocyanate, triéthylamine; Solution $S_{2}$ made of a mixture of solution $S_{1}$ and glyphosate. The blank solution was a mixture of solution $S_{1}$ and water. We used also an industrial product (Tuherb $480 \mathrm{SL}$ ). Tuherb 480 SL was provided by Callivoire (food-processing industry in Ivory Coast).
These samples were prepared for acquisition data according to the procedure below.

Preparation of the derivative glyphosate solution and the blank solution

A volume of $20.0 \mu \mathrm{L}$ of different concentrations of glyphosate solution was added to $20.0 \mu \mathrm{L}$ of $\mathrm{S}_{1}$ solution. The mixture was vigorously shaken for twenty seconds by vortex equipment, and then left at room temperature for thirty minutes. The $\mathrm{S}_{1}$ solution consists of a mixture of ethanol/triethylamine/ water/phenylisothiocyante $(7: 1: 1: 1)$.

Figure 1 shows the chemical reaction of the formation of a parent product from glyphosate. This molecule reacts with an excess of phenylisothiocyante to form phenythiocarbamoylglyphosate which is detected by UV absorbance.

The mixture thus formed is called $\mathrm{S}_{2}$ solution. The blank solution was obtained with bidistilled water and $\mathrm{S}_{1}$ solution. The mixture of water and the industrial product (Tuherb 480 SL) had also undergone same transformation like $S_{2}$ solution before analysis.

\section{Procedure}

Every five minutes, the various types of solution were evaporated under vacuum at $40{ }^{\circ} \mathrm{C}$ with Rotavapor BUCHI R-250. Each sample received again $1000 \mu \mathrm{L}$ of eluent consisted of acetonitril/water (3:7) mixture and was shaken by vortex equipment. Lastly, the tube content was transferred into a very small bottle and injected into the chromatography system for analysis.

\section{Conditions of chromatographic analysis}

The flow of the eluent within the column was $1 \mathrm{~mL} \cdot \mathrm{min}^{-1}$. The injection volume was $5 \mu \mathrm{L}$. The mobile phase was $30 \%$ acetonitril $/ 70 \%$ water, the column temperature was $30^{\circ} \mathrm{C}$ and the pressure was set at $13 \mathrm{MPa}$, and UV detector at a wavelength of $254 \mathrm{~nm}$. The recording of peaks for samples with different surfaces were realized with a microprocessor-assisted software SHIMADZU. 


\section{RESULTS AND DISCUSSION}

The various solutions of glyphosate, $S_{1}$, $\mathrm{S}_{2}$ and blank solutions are shown by recorded chromatograms in Figure 2. The chromatograms show the various peaks associated with each sample. Figure 2a presents $S_{1}$ solution; Figure $2 b$ shows peaks related to the glyphosate solution; Figure $2 \mathrm{c}$ shows the blank solution and $S_{2}$ solution is shown by Figure 2d. When comparing Figures $2 \mathrm{~b}$ and $2 \mathrm{~d}$, it can be seen that $\mathrm{S}_{2}$ solution shows two new peaks at $1.41 \mathrm{~min}$ and 4.13 min. This second peak at $4.13 \mathrm{~min}$, also appears with $S_{1}$ solution (Figure 2a), but with significant area. In this case, it could be in large amounts in $S_{1}$ solution than in $S_{2}$ solution.

It could also be attributed to phenylisothiocyanate because this component appears in the molar reaction between glyphosate and the $\mathrm{S}_{1}$ solution. Phenylisothiocyanate could be found in small quantity in $S_{2}$ solution. However, the high peak at $1.4 \mathrm{~min}$ in Figure 2d seems to be the peak attributed to phenylthiocarbamoylglyphosate which is the result of this same reaction; this enables us to follow the glyphosate content in the samples. We also observe that the peak of the blank solution (Figure 2c) is exactly the same as that of the $S_{1}$ solution (Figure 2a), with a decrease in area. This similarity seems to suggest that $S_{1}$ solution is diluted, because the blank solution was obtained by mixing bidistilled water and $\mathrm{S}_{1}$ solution.

With the blank solution, any peak appears at $1.4 \mathrm{~min}$, while it is the same method of preparation with $S_{2}$ solution, which means that the method has not created this new peak. From what is mentioned above, we can deduce that the peak corresponding to the glyphosate does not appear when it is analyzed alone (Figure 2). This peak could be seen during its reaction with $S_{1}$ solution used for the analysis. $S_{1}$ solution yielded a product more observable in chromatography and allowed us to quantify waters contaminated.

Figure 3 shows the peaks of $S_{2}$ solution samples $\left(0.5 \mathrm{mg} \cdot \mathrm{mL}^{-1}\right)$ and 480 SL Tuherb concentration $\left(0.48 \mathrm{mg} \cdot \mathrm{mL}^{-1}\right)$. Figure $3 \mathrm{a}$ relating to the $S_{2}$ solution $\left(0.5 \mathrm{mg} \cdot \mathrm{mL}^{-1}\right)$ gives identical peak at 1.5 min like the one in Figure $2 d$, but its area decreased. We deduce that the signal can be attributed to the peak observed for transformed glyphosate (phenylthiocarbamoylglyphosate). To confirm the attribution of the peak, several tests were done on samples from the company Callivoire (Ivory Coast) in order to determine the quantity of glyphosate.

All the peaks observed after glyphostate transformation have been summarized in Figure 3b. A peak at $1.6 \mathrm{~min}$, and the area corresponding to the peak is always equivalent to the sample of transformed glyphosate of $0.46 \mathrm{mg} \cdot \mathrm{mL}^{-1}$, approximately equal to that of the sample provided by the company which is 0.48 $\mathrm{mg} \cdot \mathrm{mL}^{-1}$.

All these observations show that glyphosate does not give any signal without being transformed and $S_{1}$ solution is well suited for analysis of glyphosate in water. In well-defined analytical conditions, the peak of glyphosate could occur between 1 and 2 minutes. Then, we have determined some parameters for our work to validate our method: the retention time, linearity, repeatability, accuracy, limit of detection and limit of quantification. Table 1 presents some of these parameters.

Several tests for different concentrations of $S_{2}$ solution allowed us to observe that the retention time was about 1.6 min and the surface of the individual peaks was proportional to concentrations. These figures seem to be consistent with the retention time of $1.6 \mathrm{~min}$ for glyphosate obtained for our samples with an accuracy of $5 \%$. The calibration curve between concentration and peak area observed gives a 
good correlation $\left(\mathrm{R}^{2}\right)$ of 0.99 with a slope of $5,95 \cdot 10^{-5}$. These values are very close to those generally determined into clean water $\left(10^{-6}\right)$ (Colin et al., 2010). This value does not exceed $280 \mathrm{mg} . \mathrm{L}^{-1}$ of the quantity of glyphosate.

Beyond this value, the solution seems to be too high for the chromatography to give signal. As for the values of the accuracy and the repeatability, they are well below $6 \%$, maximum average allowable for the validity of a method of analysis. The limits of detection and quantification were obtained using the bottom noise. For an average mass concentration of glyphosate of $270 \mathrm{mg} . \mathrm{L}^{-1}$, the limits of detection and quantification calculated are respectively $270 \mu \mathrm{g} . \mathrm{L}^{-1}$ and 810 $\mu \mathrm{g} . \mathrm{L}^{-1}$. These values are widely superior to the limits of detection and quantification evaluated by most researchers in the development of a measuring method of glyphosate in water (Apha, 1995).

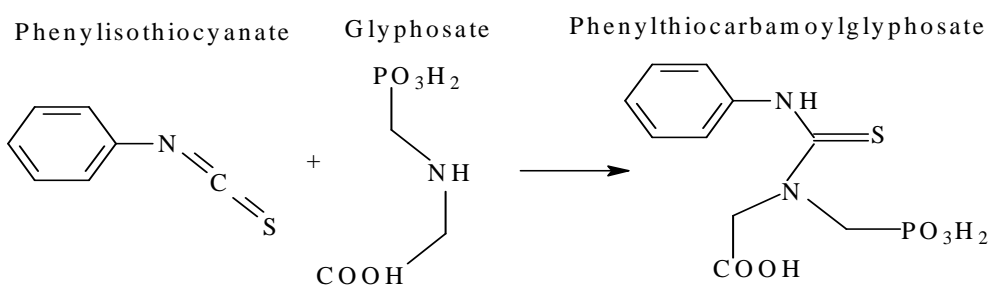

Figure 1: The glyphosate's transformation reaction.

(a)

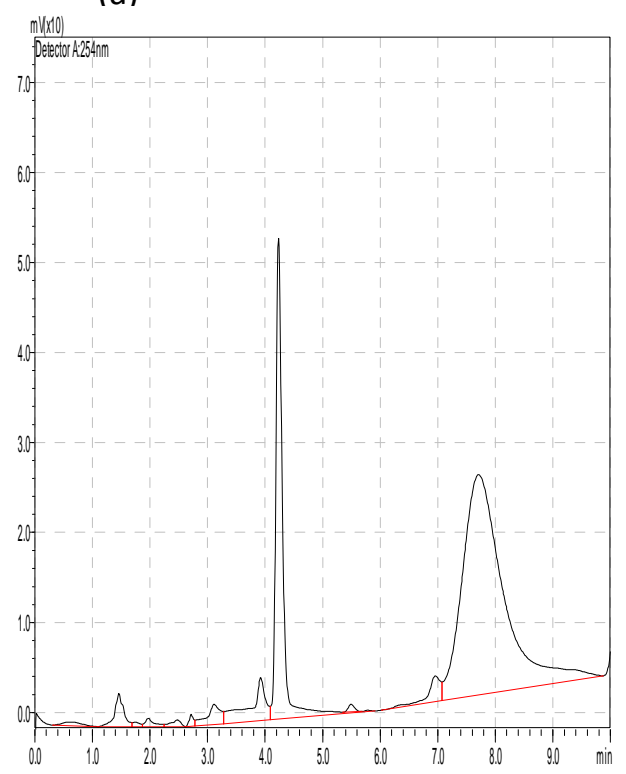

(b)

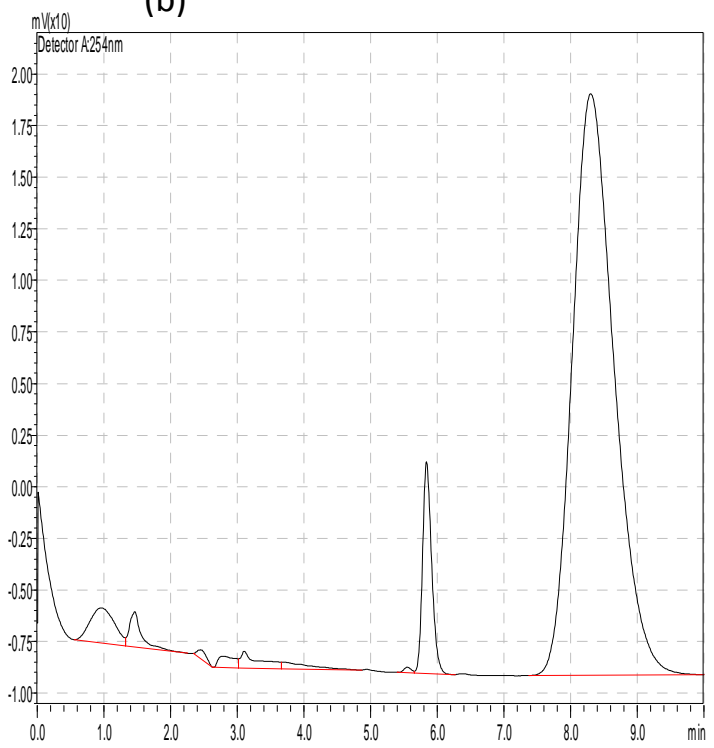


(c)

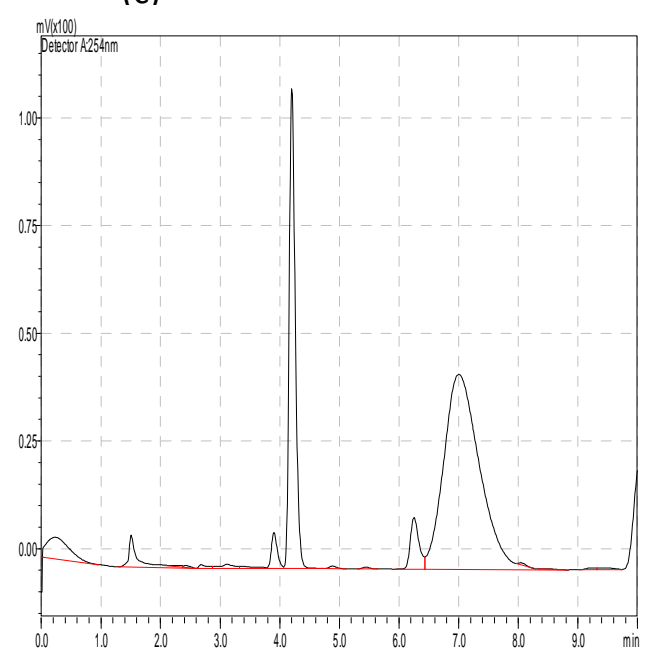

(d)

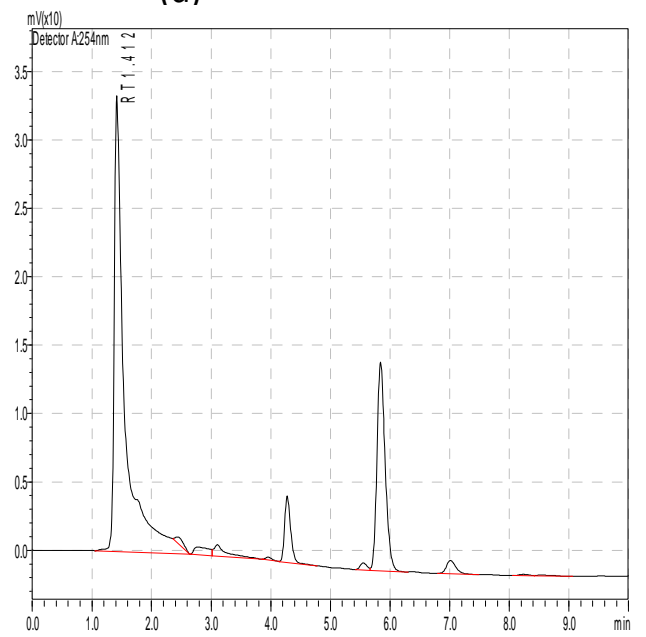

Figure 2: Chromatograms of samples: a) $S_{1}$ solution; b) glyphosate solution; c) blank solution; d) $\mathrm{S}_{2}$ solution $\left(1 \mathrm{mg} \cdot \mathrm{mL}^{-1}\right)$.

(a)

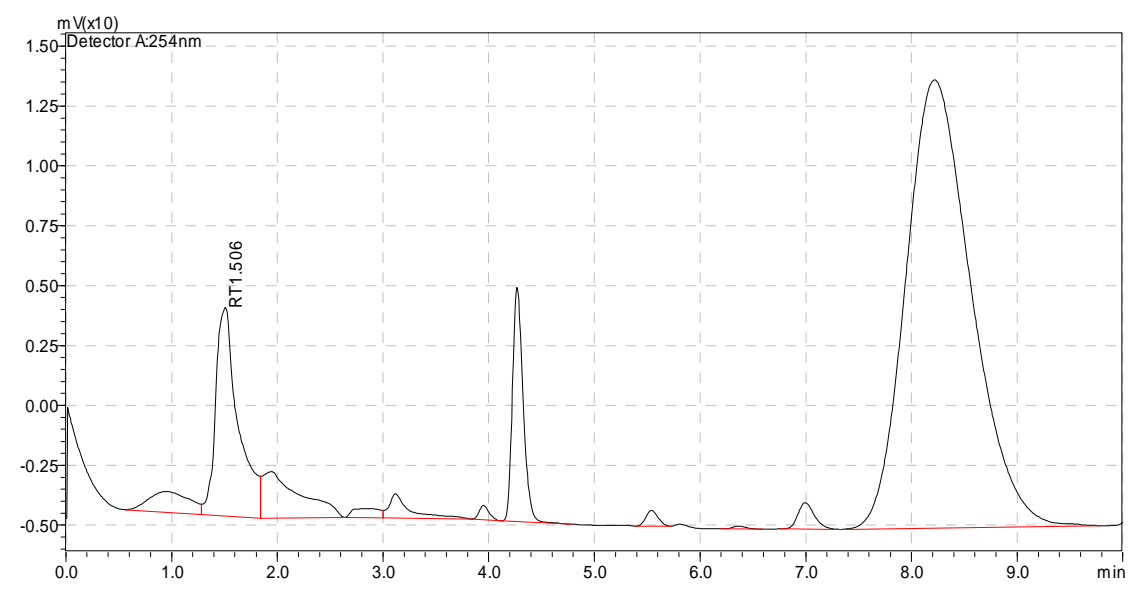

(b)

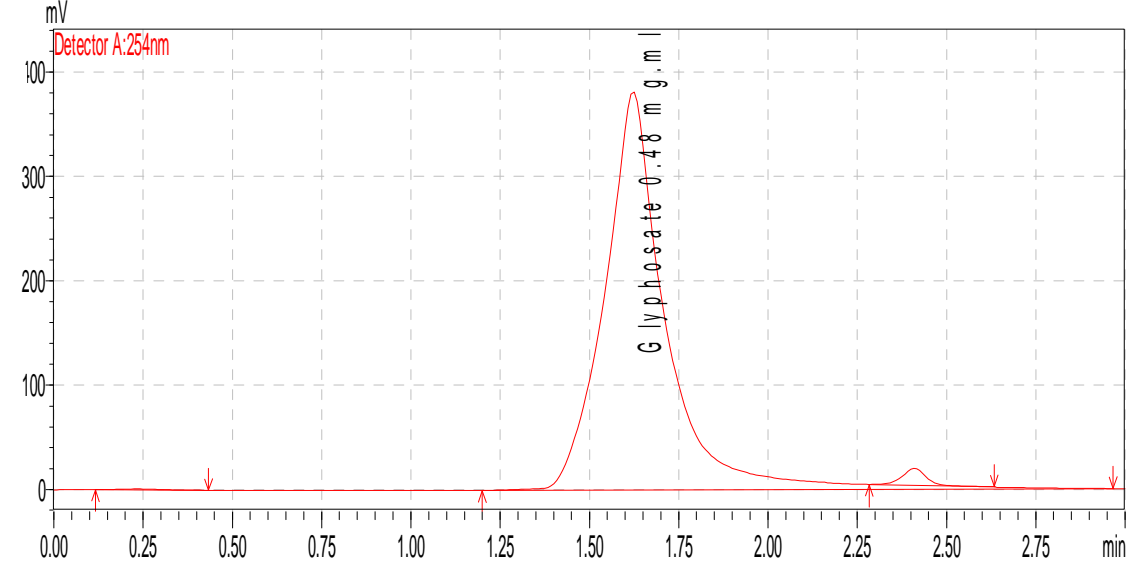

Figure 3: Chromatograms of samples: a) $\mathrm{S}_{2}$ solution $\left(0.5 \mathrm{mg} \cdot \mathrm{mL}^{-1}\right)$ b) Tuherb $480 \mathrm{SL}\left(0.48 \mathrm{mg} \cdot \mathrm{mL}^{-1}\right)$. 
Table 1: Validation settings.

\begin{tabular}{cccc}
\hline $\begin{array}{c}\text { Retention Time } \\
(\mathbf{R T})(\mathbf{m i n})\end{array}$ & $\begin{array}{c}\text { Coefficient of linear } \\
\text { correlation } \mathbf{R}^{\mathbf{2}}\end{array}$ & $\begin{array}{c}\text { Accuracy } \\
(\boldsymbol{\%})\end{array}$ & $\begin{array}{c}\text { Repeatability } \\
(\boldsymbol{\%})\end{array}$ \\
\hline 1.63 & 0.998 & 0.29 & 0.47 \\
\hline
\end{tabular}

This is the case of Colin et al. (2010) who, in their comparative study of FMOC-CI and NBD, found the limits of detection and quantification which were $0.04 \mu \mathrm{g} \cdot \mathrm{L}^{-1}$ and $0.06 \mu \mathrm{g} . \mathrm{L}^{-1}$ respectively. This big difference between our values and those of the literature may be due to the choice of $S_{1}$ solution and especially fluorescent detector that some researchers used in their method. It is all the more verified that Pablo et al. (2008), who worked in the same operating conditions, almost reached the same limits (detection and quantification) when looking for amount of glyphosate in surface water and deposits in the North Argentina. Nevertheless, the research from the Center for Research, Development and Technology (ACER) transfer in maple syrup production, has detected up to $200 \mu \mathrm{g} . \mathrm{L}^{-}$ ${ }^{1}$ amino acid in the sap (Acer, 1992). These values are often closely related to the method and especially the equipment used.

\section{Conclusion}

This work shows that glyphosate alone virtually produces no signal. To quantify it, we must perform its transformation with phenylisothiocyanate (PITC). Our results are used at the Central Laboratory of Agrochemistry and Ecotoxicology (LCAE), a technical unity of National Laboratory of Support for Agricultural Development (LANADA ) in Ivory Coast.

This method has been validated and tested extensively to analyze glyphosate at concentrations below $280 \mathrm{mg} . \mathrm{L}^{-1}$ without any step of extraction and purification. This method is accurate to $0.29 \%$ with a repeatability of $0.47 \%$ with limits of detection and quantification of $270 \mu \mathrm{g} . \mathrm{L}^{-1}$ and $810 \mu \mathrm{g} . \mathrm{L}^{-1}$ respectively.

\section{REFERENCES}

Apha. 1995. Standard Methods for the Examination of Water and Wastewaters (19th edn). American Public Health Association: Washington DC, USA.

Barja BC, Dos Santos Afonso M. 2005. Aminométhylphosphonique acid and glyphosate: adsorption onto goethite: a comparative study. Environ. Sci. Technol., 39: 585-596.

Baylis AD. 2000. Why glyphosate is a global herbicide: strengths, weaknesses and prospects. Pest. Manag. Sci., 172: 17-26.

Bidlingmeyer BA, Cohen SA, Tarvin TL, Frost B. 1987. A new, rapid, highsensitivity analysis of amino acids in food type samples. J. Assoc., Off. Anal. Chem., 70(2): 241-247.

Centre de recherche, de développement et de transfert technologique en acériculture (le centre ACER nic.). 1992. Rapport sur les travaux portant sur la recherche des acides aminés dans des échantillons de sirop de concentré d'osmose inversé et d'eau d'érable.

Colin R, Le Fur E, Charrêteur C, Dufau C, Péron JJ. 2001. Dosage du glyphosate et de l'AMPA dans l'eau. Comparaison de deux fluorophores: FMOC et NBD-CI. Colloque: Transfert des produits phytosanitaires diagnostic de pollution et solution collective.

Heinrikson RL, Meredith SC. 1984. Amino acid analysis by reverse-phase highperformance liquid chromatography: precolumn derivatization with 
phenylisothiocyanate. Anal. Biochem. 136: 65 .

James C. 2006. Global Status of commercialized Biotech/GM crops: 2006. Brief 35-2006 (Executive summary) ISAAA, Ithaca, NY, 12.

Pablo JP, Atilio AP, Alicia ER. 2008. Levels glyphosate in surface water, sediment and soils associated with direct sowing soybean cultivation in north pampasic region of Argentina. Environ. Pol., 156: 61-66.

Richard S, Moslemi S, Sipahutar H, Benachour N, Seralini GE. Jun 2005. Differential effects of glyphosate and roundup on human placental cells and aromatase. Environ. Health Perspect., 113(6): 716-720.

Sancho JV, Hernandez F, Lopez FJ. 1996. Rapid determination of glufosinate, glyphosate and aminomethylphosphonic acid in environmental water samples using precolumn fluorogenic labeling and coupled-column liquid chromatography. J. Chromatogra. A, 737: 75-83.

Savitz DA, Arbuckle Kaczor D, Curtis KM. 2000. Male pesticide exposure and pregnancy outcome. Am J. Epidemiol, 146: 1025-1036.

Tortensson L. 1985. Behaviour of glyphosate in soils and its degradation. In Herbicide Glyphosate. Gross Bard E, Atkinson D (eds). Butterworth: London, R-U; 137.

Tsui MTK, Chu LM. 2008. Environmental fate and non-taret impact of glyphosatebased herbicide (Roundup (®) in a subtropical wetland. Chemosphere, 71: 439-446.

Vereecken H. 2005. Mobility and leaching of glyphosate: a review. Pest Manag. Sci., 61: 1139-1151.

Woodburn AT. 2000. Glyphosate: production, pricing and use worldwide. Pest. Manag. Sci., 56: 309-312. 